Komunike, Volume XII, No. 2 Desember 2020

\title{
PERENCANAAN INDUSTRI MEDIA TELEVISI ISLAM
}

\author{
Ali Akbar Zubaidi \\ Fakultas Dakwah dan Komunikasi \\ Institut Agama Islam Hamzanwadi NW Pancor \\ aliakbarzubaidi@gmail.com
}

\begin{abstract}
Today, media digitalization has become the foundation of media industry owners in presenting a variety of information and entertainment, including media television. With the establishment of various commercial television broadcasting institutions as well as the competition for the media competition which is quite tight. Seeing the development of television broadcasting media itself with heavy competition, Islamic television institutions, in particular, seem not ready to compete with other television institutions. Institutions that affect the unpreparedness of existing Islamic television broadcasting institutions are planning and strategy within Islamic television broadcasting organizations and institutions, both before they come to the process of running and maintaining broadcasting institutions for a long period of time. The research method used is library research with in-depth analysis to explore problems related to the theme. The results of this study indicate that there are several things that must be planned before deciding to determine an Islamic television broadcasting institution; a) planning human resources, b) planning institutions, c) planning a product or program. When an Islamic broadcasting institution plans well, the sustainability of the Islamic broadcasting institution can be managed and run for a long time. That way, the existence of Islamic television media is indirectly able to provide another option for the public in enjoying the broadcasts that are served.
\end{abstract}

Keywords: Planning, Media Industry, Islamic Television 
Komunike, Volume XII, No. 2 Desember 2020

\begin{abstract}
Abstrak
Dewasa ini, digitalisasi media telah menjadi tumpuan para pemilik industri media dalam menyajikan beragam informasi dan hiburan tak terkecuali media televisi. Dengan berdirinya beragam lembaga penyiaran televisi komersial maupun komunitas melahirkan persaingan media yang cukup ketat. Melihat perkembangan media penyiaran televisi sendiri dengan persaingan berat, lembaga televisi Islam khususnya seakan-akan belum siap untuk bersaing dengan lembaga televisi yang lain. Alasan yang mempengaruhi ketidaksiapan lembaga penyiaran televisi Islam yang ada pada saat ini diantaranya yaitu kurangnya perencanaan dan strategi di dalam mendirikan dan mengelola lembaga penyiaran televisi Islam baik pada saat sebelum mendirikan sampai pada proses menjalankan dan mempertahankan lembaga penyiaran dalam jangka waktu yang lama. Metode penelitan yang digunakan yaitu library research dengan indepth analysis untuk mengupas permasalahan yang berkaitan dengan tema. Hasil penelitian ini menunjukkan bahwa terdapat beberapa hal yang harus direncanakan sebelum memutuskan untuk mendirikan lembaga penyiaran televisi Islam yaitu; a) merencanakan sumber daya manusia, b) merencanakan kelembagaan, c) merencanakan produk atau program. Ketika sebuah lembaga penyiaran Islam mampu merencanakan dengan baik, maka keberlangsungan lembaga media penyiaran Islam tersebut dapat dikelola dan dijalankan jangka waktu yang lama. Dengan begitu, eksistensi media televisi Islam secara tidak langsung mampu memberikan pilihan lain bagi masyarakat dalam menikmati setiap tayangan yang disuguhkan.
\end{abstract}

Kata Kunci: Perencanaan, Industri Media, Televisi Islam 


\section{A. PENDAHULUAN}

Di era masyarakat informasi, industri media massa ${ }^{1}$ harus bertransformasi dari bentuk media tradisional menjadi serba digital. Ciri khas produk teknologi di era ini menawarkan produktivitas, efisiensi, kecepatan dan lintas batas. Perangkat komunikasi audio dan visual yang sebelumnya terpisah kini berpadu dan konvergen dalam satu perangkat transmisi yang menggabungkan fungsi media penyiaran lama ke dalam satu platform media baru (new media). Semuanya didukung oleh jaringan global internet, seperti media massa, komputer, dan jaringan telekomunikasi saling berintegrasi atau belakangan lazim disebut dengan konvergensi media. ${ }^{2}$

Konvergensi media memberikan keuntungan tersendiri bagi organisasi media disebabkan dengan melipahnya sumber data dan

\footnotetext{
1 Industri media massa biasanya dianggap sebagai suatu lembaga sosial, politik dan budaya murni. Seiring dengan perkembangannya, hal tersebut menunjukkan bahwa media tidak lagi hanya dilihat sebagai suatu lembaga sosial dan politik saja, akan tetapi juga sebagai suatu lembaga ekonomi. Hal ini memandang bahwa media tidak tanya sebagai sarana untuk menyampaikan informasi sosial, politik dan budaya, melainkan sebagai perusahaan yang
}

informasi yang dapat diakses kapan saja dan dimana saja. ${ }^{3}$ Dengan perkembangan teknologi informasi yang ada pada saat ini juga turut mendorong media massa sebagai salah satu alat komunikasi. Diantara salah satu efek yang dihadirkan perkembangan teknologi informasi ini juga melahirkan banyaknya industri media penyiaran televisi.

Secara umum dengan semakin pesatnya perkembangan industri media televisi, pada dasarnya terdapat tiga sumber utama yang mendukung keberlangsungan dan eksistensi dari sebuah industri media. a) Modal, seperti pendapatan iklan, biaya berlangganan, b) Jenis konten media, seperti sinetron, informasi, hiburan, c) Jenis audiens sasaran, seperti usia, jenis kelamin, tingkat pendidikan dan sebagainya. ${ }^{4}$ Ketiga hal tersebut di atas tentu sangat bergantung kepada bagaimana pengelolaan dan

mengedepankan kepentingan di bidang ekonomi.

${ }^{2}$ Wira Respati. Transformasi Media Massa Era Masyarakat Informasi di Indonesia, (Jakarta: Humaniora, 2004) hlm. 40.

${ }^{3}$ Lisa Esti Puji Hartanti. Kebijakan Media Televisi Di Era Media Baru. Jurnal InterAct, Vol. 4 No. 1 (2015) hlm. 37-46.

${ }^{4}$ Rachmat Kriyantono, Tekhnik Praktis Riset Komunikasi, (Jakarta: Kencana Prenada Media Group, 2006) hlm. 272. 
perencanaan dari sebuah industri media televisi secara khusus.

Sebagai salah satu industri media massa, keberadaan media televisi saat ini dalam pandangan Dennis McQuail dianggap sebagai dualisme karakteristik media atau karakteristik media ganda. McQuail lebih lanjut menyatakan bahwa media memiliki dua peran yang tidak dapat dipisahkan: peran sosio-kultural, politik serta kepentingan ekonomi. Lebih lanjut, McQuail percaya bahwa faktor ekonomi telah menjadi faktor penentu yang mempengaruhi perilaku media massa modern secara keseluruhan. Selama proses komunikasi massa, faktor pasar bebas telah memberikan kontribusi penting untuk membentuk faktor persaingan. Kini, kebutuhan ekonomi telah menjadi pertimbangan bagaimana media massa kontemporer dibentuk dan dikelola.

Berkaca pada realita yang ada pada saat ini, secara khusus, industri media televisi Islam di Indonesia saat ini memiliki beragam kekurangan yang dikategorikan sebagai bagian dari masalah yang harus segera diatasi. Permasalahan yang saat ini umumnya sedang dihadapi seperti kendala dari segi pendanaan atau ekonomi, sumber daya karyawan, dan lain-lain.

Dengan segala kendala yang sedang dihadapi saat ini ditambah dengan persaingan industri media televisi yang semakin tinggi tentu akan menjadi ujian antara tetap mempertahankan ataukah tersisihkan oleh pesaing yang lain. Penelitian ini mencoba menguraikan cara merencanakan beberapa hal yang terkait dengan keberlangsungan dan eksistensi media televisi Islam di dalam mengatasi berbagai kendalakendala yang telah disebutkan sebelumnya.

\section{B. TINJAUAN PUSTAKA}

Untuk mengukur orisinilitas dari artikel ini, terdapat beberapa artikel yang menjadi pembanding yang berkaitan dengan hasil dari tulisan penelitian ini. Penelitian pertama yang dilakukan oleh Masyi 
Ari Ulinnuha, $\mathrm{dkk}^{5}$ dengan penelitan "Perancangan Stasiun Televisi Daring Untuk Memperluas Jangkauan Siar Walisongo TV" menggambarkan bahwa urgensi perancangan segala hal yang berkaitan dengan stasiun televisi daring melalui website dengan memperhatikan kualitas alat dengan ditopang oleh SDM yang baik dan peningkatan kualitas dari manajemen siaran melalui live streaming di website Walisongo TV. Persamaan dengan penelitian ini adalah perancangan siaran televisi live streaming. Sedangkan peneliti lebih menitikberatkan perencanaan industri media Islam televisi secara umum.

Penelitian kedua oleh Nunik Hariyani $^{6}$ dengan judul "Televisi Lokal Dalam Perencanaan Strategi Kreatif Program Berbasis Lokalitas Sebagai Wujud Eksistensi Media”. Nunik menitikberatkan penelitian ini terhadap keunikan program, sumber pendapatan iklan dan kemampuan

\footnotetext{
${ }^{5}$ Masy Ari Ulinnuha, dkk. dengan penelitian "Perancangan Stasiun Televisi Daring Untuk Memperluas Jangakuan Siar Walisongo TV." Walisongo Journal of Information Technology, Vol. 1 No. 1 (2019), hlm. 33-35 ${ }^{6}$ Nunik Hariyani dengan penelitian "Televisi Lokal Dalam Perencanaan Strategi Kreatif
}

inovasi dan kreatifitas di Sakti Madiun TV dengan nuansa program televisi lokal disamping mencoba untuk membangun distingsi dengan sesama TV lokal JTV Madiun. Perbedaan penelitian terletak pada perencanaan industri media televisi yang secara khusus oleh peneliti dengan mencoba untuk menjelaskan prinsip tata kelola dan perencanaan dalam membangun industri media televis Islam.

Penelitian ketiga oleh Mu'amalah $^{7}$ dengan penelitian Television: Media For Islamic Education In Millenium Era. Mu'amalah dalam penelitiannya menjelaskan tentang urgensi keberadaan televisi sebagai salah satu media pendidikan bagi anak-anak juga termasuk pengembangan masyarakat muslim. Dengan keberadaannya dapat memudahkan transformasi nilai-nilai kehidupan dan keberagamaan dalam kehidupan sehari-hari. Keberhasilan Islam dalam

Program Berbasis Lokalitas Sebagai Wujud Eksistensi Media", Sosial, Vol. 14 No. 2 (September 2013), hlm. 23-36.

${ }^{7}$ Mu'amalah, Television: Media For Islamic Education In Millenium Era, Didaktika Religia, Vol. 6 No. 1 (2018), hlm. 125-138. 
memanfaatkan teknologi untuk penyebaran ajarannya melalui media televisi dapat memudahkan orangorang memahami tujuan dari agamanya. Persamaan dalam penelitian ini terletak pada fungsi media televisi Islam sedangkan perbedaannya terletak pada tata kelola dalam industri media televisi Islam.

\section{METODE PENELITIAN}

Pada penelitian ini, pendekatan yang digunakan adalah library research dengan selalu menjadikan sumber-sumber kepustakaan sebagai data dan indepth analysis digunakan untuk mengkaji lebih mendalam terkait temuan penelitian melalui kepustakaan yang sudah dikumpulkan. Sedangkan teknik pengumpulan data yang digunakan dengan cara mengumpulkan bahanbahan kepustakaan yang memiliki keterkaitan dengan tema penelitian yang sedang dilakukan.

\section{HASIL DAN PEMBAHASAN}

Dalam merencanakan industri media televisi Islam, suatu lembaga penyiaran hendaklah terlebih dahulu memulai perencanaan melalui tiga hal pokok, yaitu perencanaan sumber daya manusia, perencanaan kelembagaan dan perencanaan produk atau program. Ketiga hal ini dapat menjamin keberlangsungan dan eksisten dari suatu lembaga penyiaran di tengah semakin kompetitifnya dunia industri penyiaran.

1. Merencanakan Sumber Daya

$$
\text { Demi keberlangsungan }
$$
lembaga penyiaran televisi Islam yang dibangun untuk jangka panjang, sebagai sebuah perusahaan industri hendaknya menjamin keberadaan media tersebut dengan lebih memperhatikan seluruh sumber daya yang ada. Penjaminan mutu maupun kualitas yang ada pada sumber daya di suatu lembaga penyiaran juga sangat menentukan perkembangan dan keberlanjutannya. Sumber daya yang perlu direncanakan dan disiapkan dalam perencanaan industri media Islam televisi, yaitu:

a. Sumber Daya Manusia

Beragam teori dan penelitian di bidang organisasi telah banyak menjelaskan tentang urgensinya peran serta dampak dari eksistensi sumber daya manusia yang secara 
khusus melibatkan organisasi maupun individu yang memiliki pengaruh bagi kinerja organisasi yang diantaranya faktor perkembangan teknologi, kepemimpinan dan inovasi. $^{8}$

Pada dasarnya, pengelolaan indsutri media televisi sama seperti pengelolaan institusi lainnya. Karena perkara yang paling mendasar untuk lebih dahulu diperhatikan adalah bagaimana para petinggi lembaga atau industri dari media televisi mengelola orang yang bekerja di dalamnya. Suatu industri media televisi akan dikatakan berhasil jika didukung oleh ide-ide kreatif para pekerja yang ada di dalam industri tersebut. Setidaknya ada tiga bidang penting dan sangat vital serta harus dimiliki dan dikembangkan oleh setiap industri media televisi yaitu: bidang teknik, program dan pemasaran. ${ }^{9}$

Kualitas setiap individu yang bekerja di tiga bidang di atas dapat

${ }^{8}$ Lambang Andri Prabawa \& Mohammad Rizan, Perkembangan Teknologi Informasi dan Komunikasi, Inovasi, Kepemimpinan dan Kinerja Perusahaan: Studi Transformasi PT. Pos Indonesia, Jurnal Pendidikan Ekonomi dan Bisnis. Vol. 3 No. 1 (1 Maret 2015), hlm. 81-100 menjamin keberhasilan suatu industri media televisi. Akan tetapi, suatu industri media televisi yang ada di dalamnya tidak bisa dijamin oleh tiap individu yang bekerja di tiga bidang tersebut jika manajemen kepemimpinan yang ada di industri media tersebut tidak matang. ${ }^{10}$ Kematangan manajemen kepemimpinan yang ada di industri tersebut juga akan menjamin keberlangsungan industri media tersebut.

Jadi, dalam perencanaan sumber daya manusia yang dimaksud di sini adalah para pekerja atau karyawan yang bertugas di setiap departmen. Mangkunegara (2006:6) menyatakan bahwa kinerja karyawan atau prestasi karyawan merupakan hasil kerja secara kualitas dan kuantitas yang dicapai seorang karyawan dalam melaksanakan tugasnya sesuai tanggung jawab yang diberikan kepadanya. Untuk meningkatkan kinerja karyawan

\footnotetext{
${ }^{9}$ Tsalis Fahmi Rahardian, Manajemen Media Televisi TV9 Nusantara: Antara Bisnis dan Dakwah dalam Perspektif Ekonomi Media. Skripsi UIN Sunan Ampel Surabaya

${ }_{10}$ Morissan, Manajemen Media Penyiaran; Strategi Mengelola Radio \& Televisi. (Jakarta: Kencana, 2008), hlm. 125.
} 
dibutuhkan banyak variabel yang mendukung, antara lain kualitas sumber daya manusia, profesionalisme kerja dan komitmen. Baiknya kualitas sumber daya manusia yang ada di dalamnya, selain itu juga didukung oleh profesionalitas dalam bekerja sesuai dengan departemen yang ditempati serta memiliki komitmen yang tinggi terhadap pekerjaannya akan mampu menampilkan kualitas terbaik bagi suatu industri media televisi Islam. ${ }^{11}$

Sumber daya manusia baru bisa dikatakan berkualitas jikalau mereka memiliki skill dalam melaksanakan kewenangan dan tanggung jawab yang ditugaskan kepadanya. Kemampuan tersebut hanya dapat dicapai jika mereka memiliki bekal pendidikan, training dan experience yang cukup dan memadai dalam melaksanakan tugas dan tanggung jawab yang diberikan. Apabila karyawan tidak memiliki kualitas yang baik maka hal tersebut dapat

\footnotetext{
11 Anwar Prabu Mangkunegara A.A, Perencanaan dan Pengembangan Manajemen Sumber Daya Manusia., (Bandung: PT. Refika Aditama, 2006), hlm. 6.

${ }^{12}$ Merisa Fajar Aisyah, dkk. Kualitas Sumber Daya Manusia, Profesionalisme Kerja, Dan
}

mempengaruhi kualitas kinerja yang dihasilkan dan memiliki dampat yang buruk perusahaan. ${ }^{12}$

Kualitas dan keahlian seorang karyawan sangat penting guna memberikan jaminan bagi suatu perusahaan dapat berkembang dan berjalan dengan baik agar tercapainya visi dan misi awal berdirinya. Pemilik media penyiaran hanya bisa mendapatkan hasil terbaik jika ia bekerja dengan orang-orang terbaik pula. Oleh karenanya, pemilik media penyiaran harus menentukan staf pelaksana media penyiaran. Memilih staf terbaik saja sebenarnya tidaklah cukup, namun diiringi dengan jaminan kebebasan untuk berkreatifitas juga perlu tapi harus disesuaikan dengan pedoman tertentu. $^{13}$

Peningkatan kualitas dan keahlian karyawan yang bekerja di suatu industri media televisi Islam terlebih dahulu harus menentukan kualifikasi-kualifikasi yang

Komitmen Sebagai Faktor Pendukung Peningkatan Kinerja Karyawan PDAM Kabupaten Jember (Jember: e-Journal Bisnis dan Akuntansi, 2017), hlm. 1-2.

13 Morissan, Manajemen Media Penyiaran; Strategi Mengelola Radio \& Televisi. (Jakarta: Kencana, 2008), hlm. 228. 
dibutuhkan untuk mencapai target dari lembaga industri tersebut.

b. Sumber Daya Ekonomi

Tak dapat dipungkiri bahwa media, terutama televisi, menjadi arus utama masyarakat untuk menerima informasi dan hiburan. Media cetak tidak terlalu besar magnetnya untuk dapat menggoda masyarakat menikmati sajian-sajiannya, kecuali kalangan tertentu saja. Demikian juga internet hanya mampu menarik kalangan muda dan terpelajar. Sementara televisi memiliki magnet yang luar biasa kuat untuk 'merayu' berbagai unsur dan lapisan masyarakat untuk menikmati sajian program atau acara yang ditayangkannya. ${ }^{14}$

Media jika di pandang dari sisi ekonomi merupakan suatu institusi bisnis atau ekonomi yang menghasilkan dan menyebarluaskan informasi, edukasi dan entertainment bagi konsumen yang menjadi target penyiaran. Konsep ekonomi media menurut Albarran menyatakan bahwa ia merupakan sebuah studi yang

14 Ropingi El Ishaq, Dakwah di Tengah Industrialisasi Media. (Kediri: FD IAIN Sunan Ampel, 2013) hlm. 144 berkaitan tentang bagaimana suatu industri media dapat memanfaatkan sumber yang terbatas untuk mendapatkan jasa yang dapat tersalurkan kepada seluruh konsumen agar dapat memenuhi beragam kebutuhan masyarakat. ${ }^{15}$

Media penyiaran televisi dengan perkembangan teknologi yang semakin maju, tentu membutuhkan dana yang besar untuk keperluan merawat dan menghargai kreatifitas para kru atau karyawan yang telah bekerja maksimal. Tanpa adanya kepastian dana, maka media penyiaran pun tak akan bisa bertahan lama. Diantara sumber keuangan bagi media sebagian besar dari iklan yang diproduksi.

Iklan bagi industri media televisi merupakan nyawa yang menjadi jaminan dan penentu dalam keberlangsungan jalannya suatu industri. Naiknya harga iklan yang ada di media televisi tercermin dengan kenaikan harga CPRP (cost per-rating point) sehingga hal ini menjadikan persaingan di antara

${ }^{15}$ Albarran, A. B., Chan-Olmsted, S. M., dan Michael O. Wirth. Handbook of Media Management and Economics. (New Jersey: Lawrence Erlbaum Associates, 2006) hlm. 6. 
stasiun media televisi semakin ketat, hal tersebut juga menjadikan peluang hidup industri media televisi yang menjadi semakin kecil. ${ }^{16}$

Iklan juga bertujuan untuk membedakan penawaran suatu produk dengan yang lainnya, juga bertujuan untuk mengkomunikasikan informasi dari suatu produk serta mendorong audiens sebagai target konsumen untuk mencoba produk baru, merangsang giatnya distribusi produk dan meningkatkan penggunaan produk. ${ }^{17}$

Iklan selain menjadi nyawa sekaligus yang dapat menjamin keberlangsungan industri media televisi, juga termasuk salah satu faktor yang mempengaruhi persaingan industri pertelevisian pada saat ini. Selain itu, ada beberapa faktor lain, turut mempengaruhi persaingan industri pertelevisian yaitu; ${ }^{18}$

16 Arif Wibawa, dkk. 2014. Model Bisnis Penyiaran Televisi Digital di Indonesia. Jurnal Ilmu Komunikasi Fakultas Ilmu Sosial \& Ilmu Psikologi (Yogyakarta: Universitas Pendidikan Nasional, 2014), hlm. 125.

17 P. C. Jha, Remica Aggarwal \& Anshu Gupta, Optimal Media Planning for MultiProduct in Segmented Market,

18 M. Adila Wiska dan Syukri Lukman. Perencanaan Strategik Media Televisi a. Rating merupakan rata-rata jumlah audiens yang menonton suatu program siaran televisi dibandingkan dengan populasi televisi yang diukur dengan berbagai skala dengan indikator tertentu. Hal ini dianggap sangat penting karena biasanya pengiklan selalu mencari yang paling banyak ditonton dalam suatu stasiun atau program siaran. ${ }^{19}$ Semakin banyak jumlah angka penilaian yang dihasilkan berupa peringkat maka semakin banyak audien yang mampu dicapai oleh sebuah stasiun televisi.

b. Jangkauan siaran.

Jangkauan siaran berdasarkan lingkup daerah siaran adalah siaran lokal dan siaran nasional serta siaran jaringan. Semakin luas siaran, maka semakin besar kemungkinan suatu industri

Dalam Persaingan di Industri Media Televisi Lokal. (Padang: Fakultas Ekonomi Universitas Andalas Padang, 2014), hlm. 6-7 19 Rizki Briandana \& Mohammad Irfan, Broadcasting Management: The Strategy of Television Production Configuring for Sustainability in the Digital Era, International Journal of English, Literature and Social Science (IJELS), Vol. 4 No. 6 (Nov-Dec 2019), hlm. 1879-1886. 
media dikenal dan diakses oleh masyarakat.

c. Segmentasi Audien.

Adalah pemetaan sasaran audien yang ingin dicapai oleh sebuah televisi dapat didasarkan pada pengelompokan audien berdasarkan: Gender atau jenis kelamin (Pria/wanita), sesuai tingkat atau jenjang usia (Anakanak, Remaja dan Dewasa), status sosial dan ekonomi, serta jenis pilihan program yang ingin ditayankan (Informasi atau Berita, Hiburan dan Pendidikan).

Audien memiliki pengaruh yang kuat dalam penentuan suatu program yang akan disajikan karena audien merupakan konsumen yang kebutuhannya harus diwujudkan dalam bentuk program acara. Salah satu wujud yang dapat mengakomodasi kebutuhan masyarakat adalah dengan dibuatnya program yang dekat dengan kehidupan mereka sehari-hari serta sesuai dengan apa yang diinginkan oleh mereka selaku audien.

d. Nominal dari suatu iklan ditentukan berdasarkan jumlah audien biasanya ditemukan berapa harga per-audien. Misalnya sebuah acara berbiaya 20 juta rupiah mendapatkan jumlah penonton sebanyak 200.000 audien maka biaya peraudien yang dihasilkan adalah 1000 per-audien.

e. Tingkat efektivitas dan efisiensi suatu iklan. Pihak pemasang iklan akan memperhitungkan tingkat efisiensi dan efektivitas iklan yang akan dipasangnya.

f. Program acara yang menarik bagi penonton. Dalam hal ini sangat diharuskan memiliki tingkat kreativitas perancang program siaran yang tinggi sehingga audien merasa terpenuhi dan terpuaskan dengan agenda acara yang disajikan dan audien akan loyal mengikuti acara berikutnya.

g. Pengelompokan stasiun-stasiun televisi. Saat ini beberapa televisi melakukan pengelompokan (grouping) karena take-over 
(pengambil-alihan kepemilikan) maupun hubungan partnership (kemitraan), maupun pengelompokkan jaringan TV lokal. Tujuan pengelompokan ini adalah untuk memperkuat daya saing, dan meningkatkan efisiensi perusahaan.

\section{Merencanakan Kelembagaan}

Pada setiap stasiun televisi lokal yang berkembang saat ini tentunya memiliki karakteristik dan ciri khas yang berbeda satu sama lain seperti, SBO TV (Suroboyo Televisi) memiliki positioning atau ciri khas sebagai televisi yang melekat dengan budaya sosial serta life style masyarakat di kota Surabaya.

Berikutnya ada Kompas TV Surabaya yang selalu menyuguhkan tayangan program televisi inspiratif serta dapat menghibur keluarga Indonesia dengan menekankan pada eksplorasi akan kekayaan sumber daya alam Indonesia, menampilkan khazanah budaya masyarakta Indonesia, hingga beragam program televisi yang menonjolkan sisi positif terhadap perkambangan dan

\footnotetext{
${ }^{20}$ Hakim Jayli. Televisi Kaum Santri, Konsep Baru Bisnis dan Tayangan Televisi di
}

gambaran situasi Indonesia pada saat ini.

Selanjutnya ada JTV yang menekankan pada aspek tayangan program yang bersifat lokal dengan menampilkan karakteristik dan ciri khas masyarakat Jawa Timur. Program yang disuguhkan banyak melibatkan masyarakat sebagai peserta. Ada juga Arek TV yang dimaknai sebagai TV yang direaktualisasi agar relevan dengan konteks kekinian. Program yang disuguhkan bertemakan egaliter, berani terbuka, semangat kolegial yang tinggi. Berikutnya ada Surabaya TV menyuguhkan program-program seputar berita ekonomi bisnis yang informatif dan mendukung dunia usaha khususnya di Surabaya dan Jawa Timur pada umumnya dan yang terakhir ada TV9 Nusantara yaitu televisi bernuansa Religi yang menekankan pada program acara yang santun, menyejukkan. ${ }^{20}$

Sebagai contoh, dari sekian banyak televisi lokal yang mulai menjamur di Surabaya, hanya TV9 Nusantara yang paling berbeda. Surabaya, 2013), hlm. 30. 
Karena TV9 Nusantara merupakan stasiun televisi lokal yang menyajikan program-program tayangannya dengan nuansa religi seperti dakwah, talkshow religi, sinema religi dan sebagainya.

Sebagai perusahaan televisi lokal, TV9 Nusantara menekankan edifikasi perusahaan dengan memberikan informasi kepada publik secara jujur, terpercaya dan mempromosikan kebaikan. Sedangkan beberapa stasiun televisi lokal lainnya lebih menekankan lifestyle kekinian dan cenderung menonjolkan kultur dari kota Surabaya. ${ }^{21}$

Kerangka rencana TV9 Nusantara dalam mencapai tujuannya yakni menjadikan TV9 Nusantara sebagai televisi religi terbaik di Indonesia dengan menyajikan tayangan yang berkualitas dan menghibur serta pengelolaan korporasi yang menguntungkan dan membanggakan. Jenis program yang mengikuti selera pasar (market

${ }^{21}$ Anisah Nur Aini. Mengukur Kepuasan TV9 Surabaya. (Surabaya: Universitas Islam Negeri Sunan Ampel Surabaya, 2016), hlm. 4.

${ }^{22}$ Dewi Anggraini, Strategi Public Relation TV9 Dalam Membangun Citra Sebagai driven), namun dengan misi, sentuhan dan angle yang khas dan berbeda yakni menggunakan perspektif kesantunan, kesejukan, yakni pendekatan keagamaan yang moderat, toleran, berimbang dan tengah. ${ }^{22}$

\section{Merencanakan Program/Produk}

Perencanaan program menurut Pringle Star sebagaimana yang dikutip oleh Morissan (2008:274) menyatakan bahwa perencanaan program merupakan segala hal yang mencakup kegiatan dalam mempersiapkan target rencana jangka pendek, menengah atau panjang yang dapat membuat stasiun televisi mencapai tujuan program dan keuangan lembaganya. ${ }^{23}$

Dalam hal ini, dengan perencanaan dan kemasan program yang menarik, tentunya audiens akan memilih siaran program sesuai dengan pilihannya. Dengan semakin banyak audiens yang menonton suatu

Televisi Lokal Religi di Surabaya. (Surabaya: Fakultas Ilmu \& Ilmu Psikologi Universitas Pendidikan Nasional Veteran Jawa Timur, 2013) hlm. 8.

${ }^{23}$ Morissan, Manajemen Media Penyiaran ..., hlm. 274. 
program, maka semakin tinggi juga rating program tersebut. ${ }^{24}$

Perencanaan program pada dasarnya bertujuan memproduksi atau membeli program yang akan ditawarkan kepada pasar audien. Tujuan dari adanya produksi program yaitu:

a) Sebagai suatu upaya untuk mempersuasi audien untuk berpartisipasi terhadap suatu fenomena atau isu tertentu yang saat itu sedang berkembang. Media televisi merupakan salah satu media yang dapat menyebarkan informasi yang cepat, akurat dan aktual. Maka media televisi selalu memberikan sajian-sajian informasi menarik, hangat dan up to date kepada audien dalm mengangkat suatu isu maupun fenomena yang tengah berkembang kepada audien.

b) Sebagai suatu upaya dalam memperluas edukasi dan pengetahuan masyarakat dalam menjembatani relasi antara masyarakat tradisionalis dengan

${ }^{24}$ Gun Gun Heriyanto, Ekonomi Politik Media Penyiaran: Rivalitas Idealisme Nilai Islami dan Mekanisme Pasar. masyarakat modernis agar dapat berperan aktif dalam menikmati tayang televisi.

Audien merupakan segmentasi pasar karenanya setiap media penyiaran yang ingin berhasil harus terlebih dahulu memiliki suatu rencana pemasaran strategis yang berfungsi sebagai panduan dalam menggunakan sumber daya yang dimiliki. Strategi pemasaran ditentukan berdasarkan analisis situasi.

Di dalam merencanakan program, termasuk hal yang paling utama untuk perlu diperhatikan di dalam menyusun dan merencanakan program adalah menganalisa khalayak. Karena khalayak merupakan para penikmat yang disuguhkan oleh media televisi. Pentingnya bagi stasiun televisi Islam di dalam menganalisa khalayak dengan menggunakan tiga tahap sebagaimana yang dijelaskan oleh

Communicatus: Jurnal Ilmu Komunikasi, Vol. 1 No. 1 (2017), hlm. 85-98. 
Kotler yaitu; segmentasi, targeting, dan positioning. ${ }^{25}$

Dalam hal ini, targeting dimaksudkan untuk menyeleksi dan memilih khalayak yang ingin dijangkau. Perencanaan program yang akan dieksekusi harus menentukan segmentasi audien yang diinginkan.

Selain itu, dalam proses penentuan target, sebuah stasiun televisi Islam dapat melakukan beberapa pilihan model targeting sebagaimana yang dijelaskan oleh Junaedi yaitu: ${ }^{26}$

1. Konsentrasi pada segmen tunggal (single segment concentration).

Pada targeting model ini, sebuah stasiun televisi Islam dapat memilih satu saja segmen khalayak. Jika perusahaan media memilih segmen yang tunggal maka perusahaan media harus memiliki pertimbangan yang kuat karena tingginya resiko kegagalan. Jika gagal membaca keinginan dan kebutuhan segmen satu khalayak, bisa saja media sudah tidak memiliki khalayak

${ }^{25}$ Fajar Junaedi. Manajemen Media Massa "Teori, Aplikasi dan Riset". (Yogyakarta: Buku Litera, 2014), hlm. 139. atau audiens yang akan menikmati setiap suguhan tayangan program lagi.

2. Spesialisasi secara selektif (selective specialization)

Spesialisasi model ini merupakan suatu proses targeting yang dilakukan oleh perusahaan dengan terlebih dahulu menentukan dan memfilter beberapa segmen saja. Segmen yang telah disaring dan ditentukan mungkin tidak saling berhubungan atau membangun sinergi. Namun setidaknya tiap-tiap segmen yang telah ditentukan tersebut masih pasti menjanjikan keuntungan.

3. Spesialisasi produk (product specialization)

Pada spesialisasi target ini, dilakukan penentuan dengan terlebih dahulu fokus pada program yang bersifat khusus. Dalam spesialisasi ini perusahaan stasiun televisi Islam terlebih dahulu melakukan pertimbangan targeting atas dasar membangun reputasi dan citra nama yang kuat di program yang spesifik.

\footnotetext{
${ }^{26}$ Fajar Juanedi, Manajemen Media Massa ..., hlm. 157
} 
Komunike, Volume XII, No. 2 Desember 2020

4. Spesialisasi market (Market Specialization)

Spesialisasi market merupakan targeting yang dilakukan dengan melihat proses dimana perusahaan lebih fokus melayani keinginan dan hajat dalam kelompok segmen tertentu. Positioning adalah bagaimana strategi untuk memasuki otak konsumen.

Segmentasi menjadi hal yang penting dalam pemasaran media. Pemasaran yang baik dimulai dari penentuan target dan pemetaan audiens. Untuk memudahkan segmentasi khalayak, Suatu stasiun televisi Islam dapat melakukan segmentasi dengan beberapa cara;

Pertama, segmentasi berdasarkan demografis. Segmentasi ini didasarkan pada data-data kependudukan, seperti usia, jenis kelamin, pekerjaan, pendidikan, agama dan lain sebagainya.

Kedua, segmentasi khalayak berdasarkan geografis. Segmentasi ini didasarkan pada wilayah kota (urban), pinggiran kota (sub-urban) dan pedesaan (rural). Khalayak yang ada di masing-masing wilayah ini tentu memiliki karakteristik yang

berbeda-beda. Contohnya, di dalam wilayah pedesaan yang identik dengan pertanian. Maka program yang coba disajikan adalah bisa saja berkaitan dengan pertanian seperti penyuluhan atau sosialisasi tentang menghasilkan tanaman yang berkualitas, baik dan lain sebagainya. Ketiga, disebut dengan istilah behavioristic segmentation yang dimana segmentasi ini ditentukan berdasarkan perilaku audiens. Segmentasi ini seringkali dimunculkan dalam bentuk kegiatan periklanan. Segmentasi ini didasarkan pada beragam variabel yang berkaitan dengan perilaku khalayak yang pada umumnya adalah status, strata sosial, dan lain sebagainya.

\section{E. KESIMPULAN}

Lembaga penyiaran televisi pada saat ini secara umum sudah sangat banyak kita temukan. Namun tidak dengan lembaga penyiaran televisi Islam. Beberapa faktor permasalahan yang menjadi kendala kenapa lembaga penyiaran televisi Islam bisa dikatakan memiliki rating yang naik turun dikarenakan adanya perencanaan yang kurang matang 
sejak sebelum didirikan menjadi faktor utamanya. Oleh karena itu, lembaga penyiaran Islam harus memiliki perencanaan yang matang dan jelas demi keberlangsungan siaran dalam jangka waktu yang panjang. Terlebih lagi, jika mampu menyaingi keberadaan lembaga penyiaran besar yang ada pada saat ini. Beberapa perencanaan yang telah dipaparkan pada pembahasan bisa menjadi langkah awal yang baik untuk mulai memperbaiki kesalahan perencanaan lembaga penyiaran televisi Islam yang masih aktif pada saat ini.
Tahap - tahap perencanaan yang harus dipersiapkan oleh lembaga penyiaran televisi Islam adalah mempersiapkan dan merencanakan sumber daya manusia yang ada di dalamnya dengan kualitas terbaik, memiliki jiwa profesionalisme yang tinggi dan mampu mengerjakan bidang-bidang tugas yang sudah ditentukan. Di samping mempersiapkan dan merencanakan sumber daya manusia, juga harus merencanakan kelembagaan suatu lembaga penyiaran televisi Islam. cakupan segmentasi yang menjadi target penyiarannya juga haruslah jelas. Terakhir juga perlunya mempersiapkan perencanaan terkait dengan program atau produk yang akan ditayangkan. 


\section{F. DAFTAR PUSTAKA}

A. Shimp, Terence. Periklanan dan Promosi; Aspek Tambahan Komunikasi Terpadu - Jilid 2. Jakarta: Erlangga, 2004.

Aini, Anisah Nur. Mengukur Kepuasan TV9 Surabaya. Surabaya: Universitas Islam Negeri Sunan Ampel Surabaya, 2016.

Aisyah, Merisa Fajar dkk. Kualitas Sumber Daya Manusia, Profesionalisme Kerja, Dan Komitmen Sebagai Faktor Pendukung Peningkatan Kinerja Karyawan PDAM Kabupaten Jember. Jember: e-Journal Bisnis dan Akuntansi, 2017.

Albarran, A. B., Chan-Olmsted, S. M., and Michael O. Wirth. Handbook of Media Management and Economics. New Jersey: Lawrence Erlbaum Associates, 2006.

Anggraini, Dewi. Strategi Public Relation TV9 Dalam Membangun Citra Sebagai Televisi Lokal Religi di Surabaya. Surabaya: Fakultas Ilmu \& Ilmu Psikologi Universitas Pendidikan Nasional Veteran Jawa Timur, 2013.

Briandana, Rizki \& Mohammad Irfan, Broadcasting Management: The Strategy of Television Production Configuring for Sustainability in the Digital Era, International Journal of
English, Literature and Social Science (IJELS), Vol. 4 No. 6, Nov-Dec 2019.

El Ishaq, Ropingi. Dakwah di Tengah Industrialisasi Media. Kediri: FD IAIN Sunan Ampel, 2013.

Hariyani, Nunik. "Televisi Lokal Dalam Perencanaan Strategi Kreatif Program Berbasis Lokalitas Sebagai Wujud Eksistensi Media", Sosial, Vol. 14 No. 2, September2013.

Hartanti, Lisa Esti Puji. Kebijakan Media Televisi Di Era Media Baru. Jurnal InterAct, Vol. 4 No. 1, 2015.

Heriyanto, Gun Gun. Ekonomi Politik Media Penyiaran: Rivalitas Idealisme Nilai Islami dan Mekanisme Pasar. Communicatus: Jurnal Ilmu Komunikasi, Vol. 1 No. 1, 2017.

Jayli, Hakim. Televisi Kaum Santri, Konsep Baru Bisnis dan Tayangan Televisi di Gerbang Era TV Digital. Surabaya: TV9 Surabaya, 2013.

Junaedi, Fajar. Manajemen Media Massa "Teori, Aplikasi dan Riset”. Yogyakarta: Buku Litera, 2014.

Kriyantono, Rachmat. Tekhnik Praktis Riset Komunikasi. Jakarta: Kencana Prenada Media Group, Edisi Pertama, 2006. 
Mangkunegara A.A, Anwar Prabu. Perencanaan dan Pengembangan Manajemen Sumber Daya Manusia. PT. Refika Aditama, 2006.

Morissan. Manajemen Media Penyiaran; Strategi Mengelola Radio \& Televisi. Jakarta: Kencana. 2008.

Mu'amalah, Television: Media For Islamic Education In Millenium Era, Didaktika Religia, Vol. 6 No. 1, 2018.

Prabawa, Lambang Andri \& Mohammad Rizan, Perkembangan Teknologi Informasi dan Komunikasi, Inovasi, Kepemimpinan dan Kinerja Perusahaan: Studi Transformasi PT. Pos Indonesia, Jurnal Pendidikan Ekonomi dan Bisnis. Vol. 3 No. 1, Maret 2015.

Rahardian, Tsalis Fahmi. Manajemen Media Televisi TV9 Nusantara: Antara Bisnis dan Dakwah dalam Perspektif Ekonomi Media. UIN Sunan Ampel Surabaya, 2018.
Respati, Wira. Transformasi Media Massa Era Masyarakat Informasi di Indonesia. Jakarta: Humaniora, 2004.

Suandy, Erly. Perencanaan Pajak, Edisi 1. Jakarta: Salemba Empat, 2001.

Ulinnuha, Masy Ari. dkk. dengan penelitian "Perancangan Stasiun Televisi Daring Untuk Memperluas Jangakuan Siar Walisongo TV." Walisongo Journal of Information Technology, Vol. 1 No. 1, 2019.

Wibawa, Arif dkk. Model Bisnis Penyiaran Televisi Digital di Indonesia. Yogyakarta: Jurnal Ilmu Komunikasi Fakultas Ilmu Sosial \& Ilmu Psikologi Universitas Pendidikan Nasional, 2014.

Wiska, M. Adila \& Syukri Lukman. Perencanaan Strategik Media Televisi Dalam Persaingan di Industri Media Televisi Lokal. Padang: Fakultas Ekonomi Universitas Andalas Padang, 2014. 